\title{
Pancreatic peripheral primitive neuroectodermal tumor diagnosed by endoscopic ultrasound
}
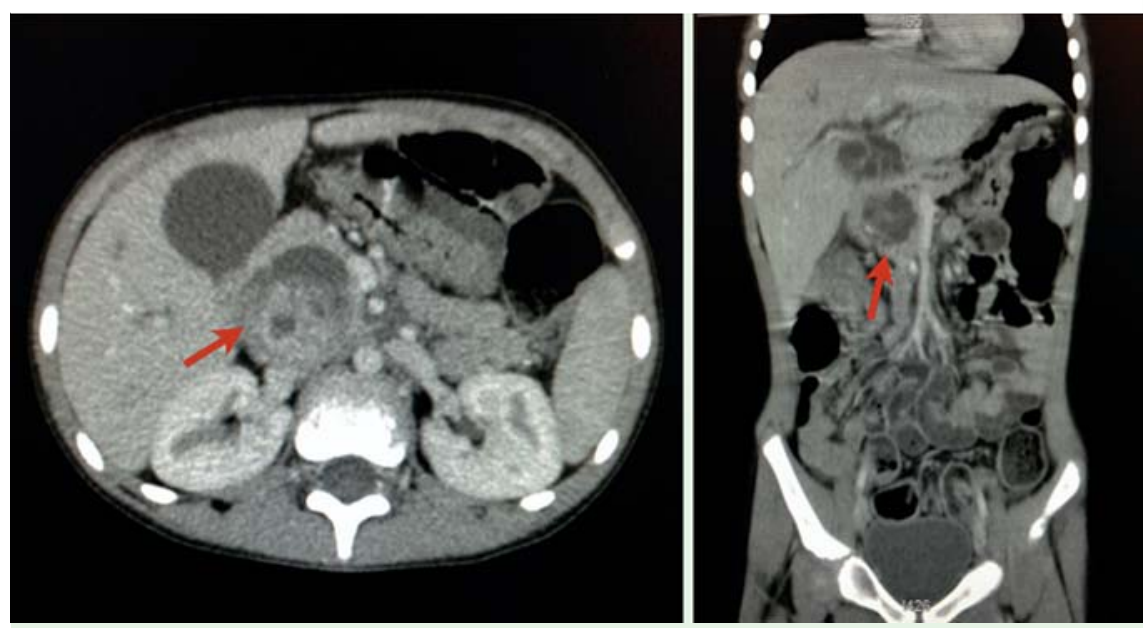

Fig. 1 Pancreatic peripheral primitive neuroectodermal tumor. Computed tomography in axial (left panel) and coronal (right panel) views showing a $4.5 \times 4.0-\mathrm{cm}$ well-delimited mass in the head of the pancreas (red arrows) with heterogeneous content, foci of calcification, and cystic/necrotic areas.

An 8-year-old girl presented with abdominal pain and jaundice of 1 month's duration. She had conjugated hyperbilirubinemia and negative hepatitis serology. Computed tomography showed a mass in the head of the pancreas, with foci of calcification and cystic/necrotic areas ( $\bullet$ Fig. 1). Pancreatoblastoma and Frantz tumor were suspected. The patient underwent a cholecystojejunal anastomosis, and intraoperative biopsy of the pancreatic mass yielded inconclusive results. She was referred for endoscopic ultrasound (EUS) to re-evaluate the pancreatic mass. EUS showed a solid-cystic lesion in the head of the pancreas without vascular in- volvement ( Fig. 2, Fig.3). The main pancreatic duct and common bile duct were slightly dilated. EUS-guided fineneedle aspiration of the pancreatic mass was done with a 22-gauge needle (EchoTip; Cook Medical, Limerick, Ireland) ( Fig.4). Cytopathologic evaluation of cell block material revealed a small cell neoplasm, and immunohistochemical analysis confirmed the diagnosis of peripheral primitive neuroectodermal tumor (PNET) ( Fig. 5, $\bullet$ Fig. 6).

PNET belongs to a rare group of tumors called the Ewing sarcoma family of tumors [1 - 3]. Few PNETs arise in solid organs, and pancreatic PNETs are extremely rare [4-
8]. Pancreatic PNETs are highly aggressive. Metastasis and recurrence are common, so that the prognosis is very poor. With modern multidisciplinary treatment, longterm survival can be achieved in $70 \%$ to $80 \%$ of patients with disease that has not metastasized [9].

The correlation of clinical symptoms with imaging, cytopathologic, and immunohistochemical analysis is useful to establish the diagnosis [10,11]. An atypical rosette array of the cells, cytoplasmic neuronal secretory granules and neurofilaments, and pyknotic nuclear granules are important diagnostic criteria $[4-8,12]$. Most tumors of the Ewing sarcoma family express high levels of a cell surface glycoprotein, CD99 [13,14].

According to a 2014 review article [15], 14 cases of pancreatic PNET have been reported. This is the first case of a pancreatic PNET diagnosed by EUS.

Endoscopy_UCTN_Code_CCL_1AF_2AZ_3AB

Competing interests: None

Flávio Amaro, Rogério Colaiácovo, Augusto Carbonari, Mauro Saieg, Ana Claudia Baraldi, Lúcio Rossini

Centro Franco Brasileiro de Ecoendoscopia (CFBEUS), Santa Casa de São Paulo,

São Paulo, Brazil

\section{References}

1 Askin FB, Rosai J, Sibley RK et al. Malignant small cell tumor of the thoracopulmonary region in childhood: a distinctive clinicopathologic entity of uncertain histogenesis. Cancer 1979; 43: 2438-2451

2 Llombart-Bosch A, Lacombe MJ, Contesso G et al. Small round blue cell sarcoma of bone mimicking atypical Ewing's sarcoma with neuroectodermal features. An analysis of
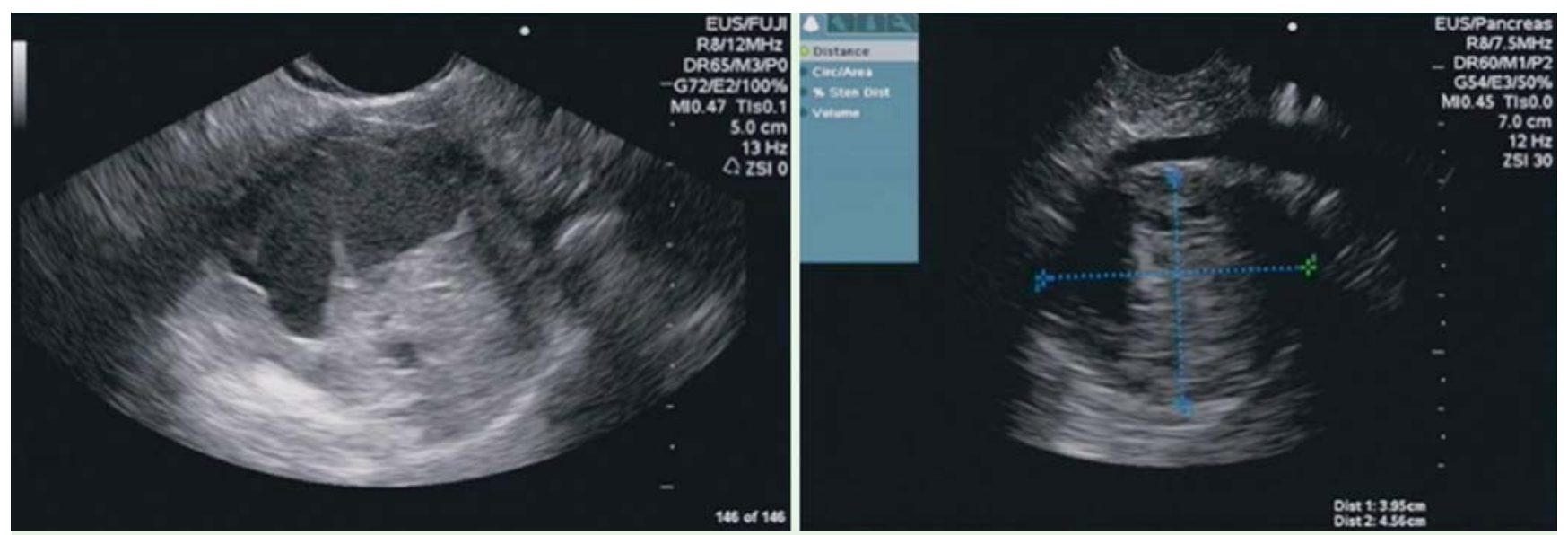

Fig. 2 Endoscopic ultrasound (stomach views) showing a solid cystic heterogeneous lesion in the pancreatic head. 


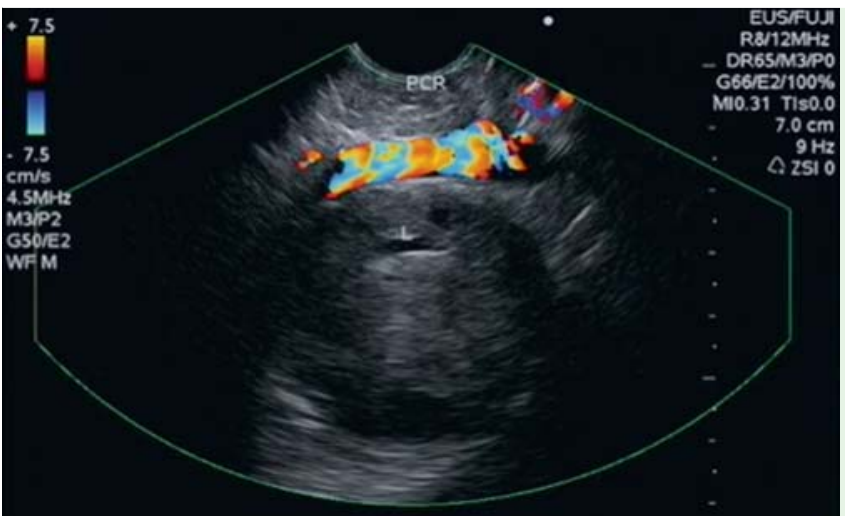

Fig. 3 Endoscopic ultrasound (stomach view) showing no echographic signs of portal vein impairment.

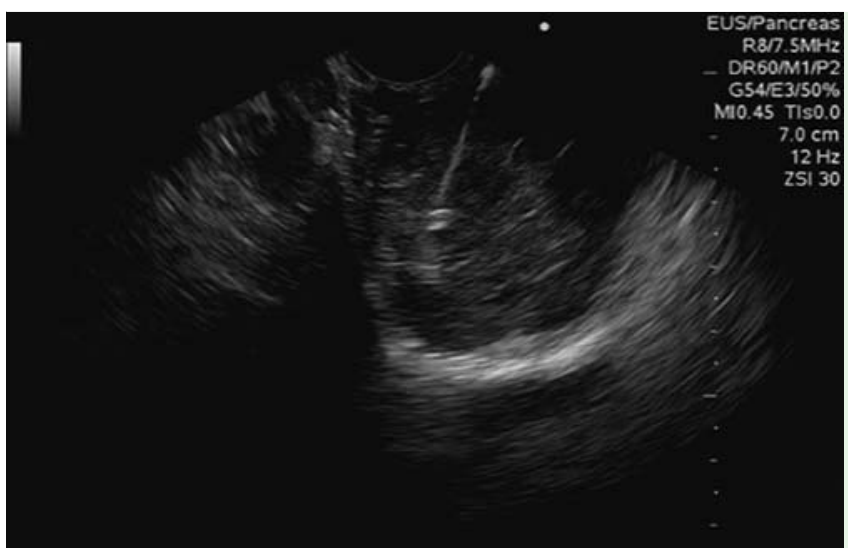

\begin{tabular}{|l|}
\hline CEA \\
\hline D1 CYCLIN \\
\hline SYNAPTOPHYSIN \\
\hline CHROMOGRANIN \\
\hline Alpha-fetoprotein \\
\hline Beta-catenin \\
\hline CK7 \\
\hline Ki-67 \\
\hline Tdt \\
\hline Alpha,-antitrypsin \\
\hline VIMENTIN \\
\hline CD99 \\
\hline FLY-1 \\
\hline
\end{tabular}

\begin{tabular}{l} 
Negative \\
Focal positive \\
\hline Focal positive \\
Negative \\
Negative \\
Negative \\
Negative \\
Positive in $30 \%$ of neoplastic cells \\
Negative \\
Negative \\
\hline Negative \\
\hline Positive \\
\hline Focal positive \\
\hline
\end{tabular}

Fig.5 Immunohistochemical profile suggestive of primitive neuroectodermal tumor. CEA, carcinoembryonic antigen; CK, cytokeratin; Tdt, terminal deoxynucleotidyl transferase; $C D$, cluster of differentiation. five cases with immunohistochemical and electron microscopic support. Cancer 1987; 60: $1570-1582$

3 Grier HE. The Ewing family of tumors. Ewing's sarcoma and primitive neuroectodermal tumors. Pediatr Clin North Am 1997; 44: 991 - 1004

4 Movahedi-Lankarani S, Hruban RH, Westra $W H$ et al. Primitive neuroectodermal tumors of the pancreas: a report of seven cases of a rare neoplasm. Am J Surg Pathol 2002; 26: 1040-1047

5 Bülchmann G, Schuster T, Haas RJ et al. Primitive neuroectodermal tumor of the pancreas. An extremely rare tumor. Case report and review of the literature. Klin Padiatr 2000; 212: 185 - 188

6 Perek S, Perek A, Sarman $K$ et al. Primitive neuroectodermal tumor of the pancreas. A case report of an extremely rare tumor. Pancreatology 2003; 3: 352-356

7 Danner DB, Hruban RH, Pitt HA et al. Primitive neuroectodermal tumor arising in the pancreas. Mod Pathol 1994; 7: 200-204

8 Lüttges J, Pierré E, Zamboni G et al. Malignant non-epithelial tumors of the pancreas. Pathologe 1997; 18: 233 -237

9 Granowetter $L$, Womer R, Devidas $M$ et al. Dose-intensified compared with standard chemotherapy for nonmetastatic Ewing sarcoma family of tumors: a Children's Oncology Group Study. J Clin Oncol 2009; 27 : 2536-2541

10 Panicek DM, Gatsonis C, Rosenthal DI et al. CT and MR imaging in the local staging of primary malignant musculoskeletal neoplasms: report of the Radiology Diagnostic Oncology Group. Radiology 1997; 202: 237-246

11 Fuccio L, Larghi A. Endoscopic ultrasoundguided fine needle aspiration: how to obtain a core biopsy? Endosc Ultrasound 2014; 3: $71-81$

12 Papierz W, Alwasiak J, Kolasa P et al. Primitive neuroectodermal tumors: ultrastructural and immunohistochemical studies. Ultrastruct Pathol 1995; 19: 147-166

13 Ambros IM, Ambros PF, Strehl S et al. MIC2 is a specific marker for Ewing's sarcoma and peripheral primitive neuroectodermal tumors. Evidence for a common histogenesis of Ewing's sarcoma and peripheral primitive
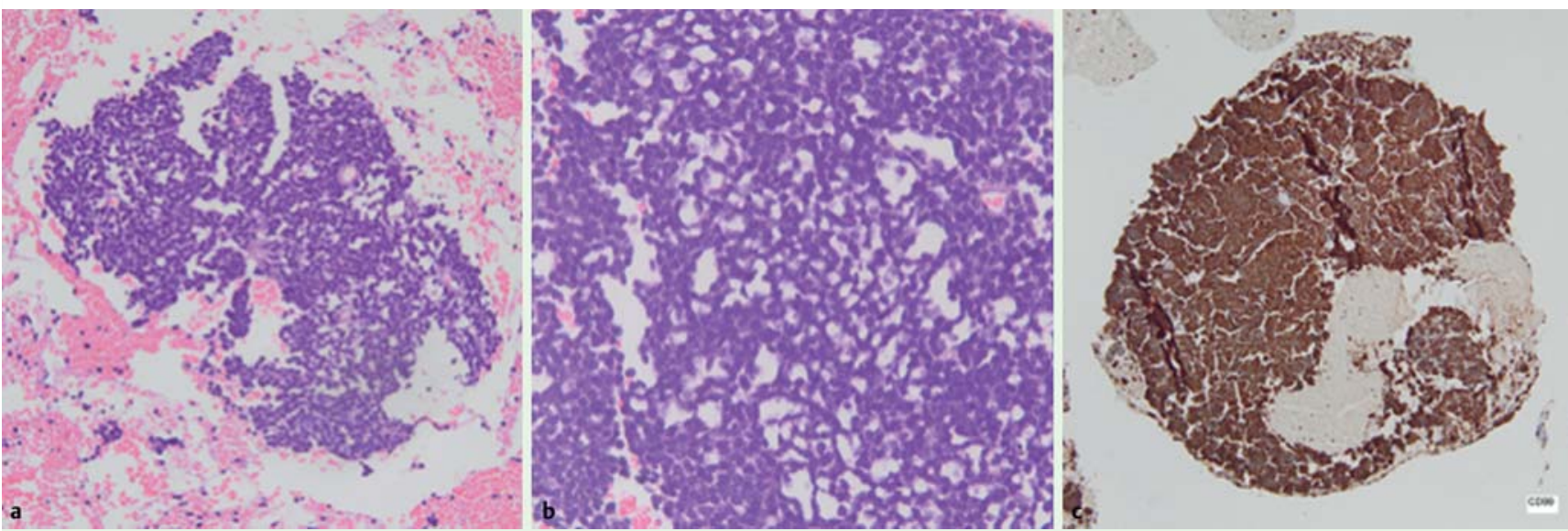

Fig. 6 Pancreatic peripheral primitive neuroectodermal tumor. a Cell block section showing clusters of rather uniform neoplastic cells arranged in a lobular pattern (hematoxylin and eosin, original magnification $\times 10$ ). $\mathbf{b}$ Details of the neoplastic cells, showing scant cytoplasm, mild atypia, and a trabecular architecture. c Immunohistochemical reaction showing strong diffuse positivity for CD99. 
neuroectodermal tumors from MIC2 expression and specific chromosome aberration. Cancer 1991; 67: 1886-1893

14 Fellinger EJ, Garin-Chesa P, Triche TJ et al. Immunohistochemical analysis of Ewing's sarcoma cell surface antigen p30/32MIC2. Am J Pathol 1991; 139: 317-325

15 Mao Y, Sang $X$, Liang NX et al. Peripheral primitive neuroectodermal tumors arising in the pancreas: the first case report in Asia and a review of the 14 total reported cases in the world. Hepatobiliary Surg Nutr 2013; 2: $51-60$
Bibliography

Dol http://dx.doi.org/

10.1055/s-0034-1377982

Endoscopy 2015; 47: E11-E13

(c) Georg Thieme Verlag KG

Stuttgart · New York

ISSN 0013-726X
Corresponding author

Flávio Amaro, MD

Rua Haddock Lobo 807, Apt. 14

São Paulo, São Paulo 01414-001

Brazil

flavioamaro.obs@gmail.com 